\title{
Immunotherapy in Non-Small Cell Lung Cancer Patients with Brain Metastases: Clinical Challenges and Future Directions
}

\author{
Ranjan Pathak ${ }^{1, *}$, Arya Amini $^{2}$, Addie Hill $^{1}$, Erminia Massarelli ${ }^{1}$ (D) and Ravi Salgia ${ }^{1}$ D \\ 1 Department of Medical Oncology and Therapeutics Research, City of Hope, Duarte, CA 91010, USA; \\ ahill@coh.org (A.H.); emassarelli@coh.org (E.M.); rsalgia@coh.org (R.S.) \\ 2 Department of Radiation Oncology, City of Hope, Duarte, CA 91010, USA; aamini@coh.org \\ * Correspondence: rpathak@coh.org
}

check for

updates

Citation: Pathak, R.; Amini, A.; Hill,

A.; Massarelli, E.; Salgia, R.

Immunotherapy in Non-Small Cell

Lung Cancer Patients with Brain

Metastases: Clinical Challenges and

Future Directions. Cancers 2021, 13,

3407. https://doi.org/10.3390/

cancers13143407

Academic Editor:

Alejandro Lopez-Soto

Received: 9 June 2021

Accepted: 29 June 2021

Published: 7 July 2021

Publisher's Note: MDPI stays neutral with regard to jurisdictional claims in published maps and institutional affiliations.

Copyright: (c) 2021 by the authors. Licensee MDPI, Basel, Switzerland. This article is an open access article distributed under the terms and conditions of the Creative Commons Attribution (CC BY) license (https:// creativecommons.org/licenses/by/ $4.0 /)$.
Simple Summary: Although brain metastasis is a common and serious complication in lung cancers, current therapies with surgery, radiation, and traditional systemic agents are insufficient. Recently, immunotherapy has been shown to be effective against brain metastases in lung cancers, paving the way for a newer generation of systemic therapies. This review attempts to summarize our current understanding of immunotherapy in lung cancer brain metastases and explores future directions for research.

\begin{abstract}
Immune checkpoint inhibitors have revolutionized the treatment landscape for patients with non-small cell lung cancers. Existing treatment paradigms for brain metastases in lung cancer patients leave patients with adverse neurocognitive function, poor quality of life, and dismal prognosis, thus highlighting the need to develop more effective systemic therapies. Although data are limited, emerging knowledge suggests promising activity and safety of immune checkpoint inhibitors in brain metastases in non-small cell lung cancer patients. This review aims to summarize the current data, highlight the challenges of incorporating immune checkpoint inhibitors in treating these patients, and identify areas for future research.
\end{abstract}

Keywords: non-small cell lung cancer; brain metastasis; PD-1; PD-L1; immunotherapy; immune checkpoint inhibitors

\section{Introduction}

Brain metastasis (BM) is a common and grave complication in non-small cell lung cancer (NSCLC). Almost a third of NSCLC patients develop brain metastasis at some point during their disease course, with higher rates reported in patients with epidermal growth factor receptor (EGFR) and anaplastic lymphoma kinase (ALK) mutations [1-3]. BMs are associated with adverse neurocognitive function, poor quality of life, and dismal prognosis despite multidisciplinary treatment with surgery, radiation therapy (RT), and systemic agents [4]. There is, therefore, a critical need for more effective therapies for NSCLC patients with BMs.

Over the past few decades, understanding of tumor biology and the immune system has led to the development of immune checkpoint inhibitors (ICIs) that have revolutionized the treatment landscape for patients with advanced NSCLC. Blocking the programmed death protein-1 (PD-1), its ligand (PD-L1), and cytotoxic T-lymphocyte-associated protein 4 (CTLA-4) pathways has led to remarkable improvements in the outcomes of these patients.

There are, however, limited data on the central nervous system (CNS) efficacy of ICIs, as most of the pivotal trials on ICIs excluded or underrepresented patients with BMs [5]. Some of the reasons for excluding these patients include concerns about the ability of monoclonal antibodies such as ICIs to penetrate the blood-brain barrier, diminished efficacy of ICIs due to concurrent steroid use, and hyperprogression of BMs [6,7]. Despite 
these concerns, several retrospective studies and prospective trials point toward the activity and safety of ICIs in NSCLC patients with BMs.

In this review, we aim to summarize the current clinical evidence for the efficacy of ICIs in NSCLC patients with BMs, highlight the challenges of incorporating ICIs in treating these patients, and identify areas for future research.

\section{BM Inflammatory Microenvironment and Rationale for ICI-Based Treatment}

Recent studies evaluating the immune system and tumor microenvironment (TME) have challenged the long-held view of the brain as an immune-isolated compartment [8]. It is now known that the brain parenchyma is an immunologically active organ that initiates and regulates immune responses [9]. The inflammatory TME of BMs consists of the innate immune system, namely microglia and blood-derived myeloid cells/macrophages, and the adaptive immune system, mainly represented by T cells [10]. Varying degrees of T cell infiltration or tumor-infiltrating lymphocytes (TILs) have been observed in BMs [11,12]. Patients with BMs with dense infiltration of effector CD3+, cytotoxic CD8+, or memory CD45RO+ TILs have been found to have improved survival compared with patients with low or absent TILs [13]. Unlike cytotoxic chemotherapy and targeted therapies, because ICIs act by removing the inhibition of T cells by tumor cells, immune cell trafficking of peripherally activated T cells into the CNS is perhaps more critical than the penetration of the blood-brain barrier by the ICIs themselves [9]. However, recent observations have suggested that cerebrospinal fluid concentrations of systemically administered pembrolizumab (which were $1 \%$ of serum concentrations) can functionally block PD-1 on T cells [14]. These observations, along with the recent discovery of the CNS lymphatic system and TME preconditions in the CNS that mimic extracranial metastases $[15,16]]$ are challenging our long-held notions of immune privilege in the CNS and support the clinical development of ICI-based strategies in patients with BMs.

\section{Safety and Efficacy of ICIs in Patients with NSCLC BMs}

Currently, there are limited prospective data on the efficacy and safety of ICIs in NSCLC patients with BMs. Patients with BMs have historically been underrepresented in the clinical trials of ICIs in NSCLC. For example, a study by El Rassy et al. found that only $6.2-17.5 \%$ of the patients enrolled in the pivotal NSCLC trials had asymptomatic or previously treated and stable BMs, and none of them allowed patients with symptomatic or untreated BMs [5]. Besides, the majority of these trials do not report intracranial efficacy and other outcomes stratified by the presence or absence of BMs. As a result, our current understanding of the efficacy and safety of ICIs in BMs in NSCLC have primarily been derived from the single-arm phase 1-2 trials [17,18], expanded access programs [19-21], post hoc/pooled analyses of clinical trials [22-27], and retrospective series [28-35].

\subsection{Untreated BMs}

Given the concerns for increasing peritumor inflammation and vasogenic edema, the majority of ICI trials have excluded NSCLC patients with BMs that have not received local therapies such as RT. However, recent data presented below challenge this notion and provide evidence that ICI therapy by itself might be able to achieve intracranial response with acceptable safety in a select group of patients.

\subsubsection{ICI Monotherapy}

Goldberg et al. have recently reported an updated analysis of the NSCLC cohort of their phase 2 trial of pembrolizumab in patients with NSCLC or melanoma with untreated brain metastases [18]. Forty-two patients with stage IV non-oncogene driven, ICI-naïve NSCLC with at least one asymptomatic BM measuring 5-20 $\mathrm{mm}$ in size, not previously treated or progressing after previous RT, and not requiring steroids, were treated with pembrolizumab $10 \mathrm{mg} / \mathrm{kg}$ intravenously every 2 weeks. After a median follow-up of 8.3 months, $11(29.7 \%$, 95\% CI, 15.9-47.0) of 37 patients in cohort 1 showed intracranial 
response with a CNS progression-free survival (PFS) of 2.3 months (95\% CI, 1.9-not reached) with almost one-third of patients remaining progression-free in the CNS at 1 year. Thirtyfour percent (95\% CI 21-54) of the patients were alive at 2 years. No responses were seen in the PD-L1 negative patients (5 patients in cohort 2). Treatment-related serious adverse events occurred in $6(14 \%)$ of 42 patients and were comparable with adverse events reported in other ICI trials. No treatment-related neurological adverse events were noted. This study provides a prospective proof of concept for the intracranial activity of ICI in patients with NSCLC (Table 1).

Another prospective trial that specifically evaluated NSCLC patients with untreated BMs was the Checkmate 012 [17]. Patients in "arm M" of this phase 1 trial included 12 patients with at least one asymptomatic and untreated BM up to $30 \mathrm{~mm}$ in size. Patients were required to have at least one prior systemic therapy for NSCLC and could have up to four BMs. Two intracranial responses were observed (16.7\%, 95\% CI, 2.1-48.4) and the median PFS was 1.6 months (95\% CI 0.92-2.50) with a median overall survival (OS) of 8.0 months (95\% CI, 1.38-15.50). Similarly to the study by Goldberg et al., no treatment-related neurologic adverse events were reported.

Several other ongoing single-arm phase 2 trials are evaluating the role of ICI in patients with untreated BMs (Clinicaltrials.gov NCT02681549, NCT02886585, NCT03526900) (Table 2). The intracranial efficacy will be measured by modified RECIST in the first study, while Response Assessment in Neuro-Oncology Brain Metastases (RANO-BM) criteria will be used for the other two studies [36].

In addition to these prospective trials, several other retrospective studies have suggested the potential efficacy of ICI alone in untreated BMs and are summarized in Table 1. However, the patients in the above studies were highly selected and only included patients that had small BMs and were asymptomatic. Therefore, further studies are needed to better clarify the efficacy and safety of ICI alone for untreated BMs that are larger or are symptomatic.

\subsubsection{Concurrent ICI and RT}

The addition of RT to ICI has been investigated as a means to create synergy between the two treatment modalities by priming the immune response and, possibly, an abscopal response (tumor regression at a site distant from the primary site of radiotherapy) [37,38]. Although RT can lead to leukopenia and cause immunosuppression, it can also stimulate the innate and adaptive immune system through the release of tumor cell antigens and activation of critical molecular pathways, including increased PD-L1 expression [39,40].

Several studies, including a meta-analysis of retrospective data on stereotactic radiosurgery (SRS) and ICI, have suggested better OS with concurrent rather than sequential ICI and SRS [41,42]. Ahmed et al. reported retrospective data on NSCLC BM patients who received SRS and anti-PD-1/PD-L1 therapy [43]. Patients who received RT during or before ICI therapy achieved better distant brain control rate at 6 months compared with patients who received ICI before RT. The rate of acute neurotoxicity was similar among patients who received SRS alone or with ICI (ICI was given either within 2 weeks of SRS or afterward). Grade 3 acute CNS toxicity was similar between the two interventions.

Discussion on the optimal timing and dosing of RT with ICI was outside the scope of this review, and the results of ongoing clinical trials of RT in patients with BMs are expected to give more insight into this important clinical question (such as NCT02696993, NCT02858869, NCT02710253). 
Table 1. Summary of clinical studies with immune checkpoint inhibitors in patients with brain metastases.

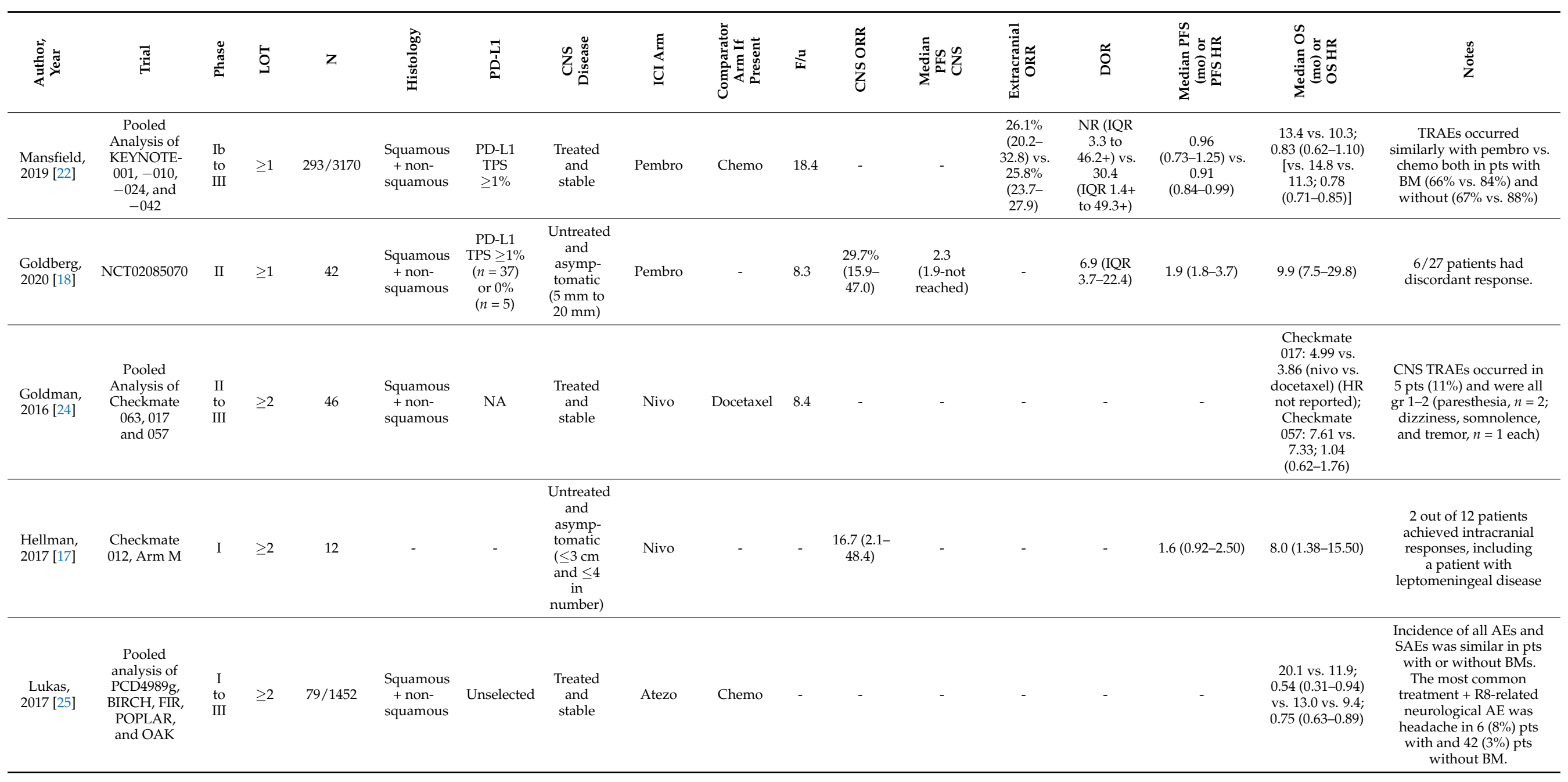


Table 1. Cont.

\begin{tabular}{|c|c|c|c|c|c|c|c|c|c|c|c|c|c|c|c|c|c|c|}
\hline 章 & 馬 & $\begin{array}{l}\mathscr{\mathscr { N }} \\
\stackrel{\Xi}{E}\end{array}$ & o & $z$ & 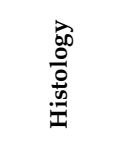 & $\overrightarrow{1}$ & 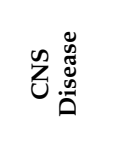 & 恶 & 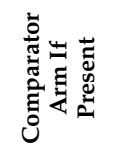 & 疍 & $\begin{array}{l}\approx \\
\tilde{z} \\
\text { on } \\
\text { U }\end{array}$ & 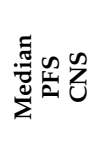 & 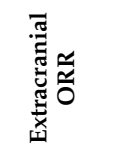 & оั & 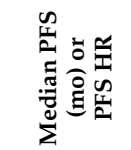 & \multicolumn{2}{|c|}{ 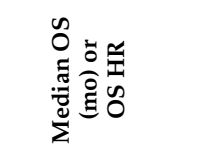 } & 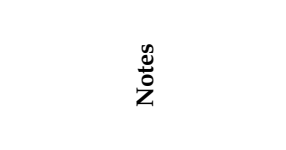 \\
\hline $\begin{array}{l}\text { Hendriks, } \\
2019 \text { [28] }\end{array}$ & $\begin{array}{l}\text { Retrospective } \\
\text { study that } \\
\text { included } \\
\text { patients on } \\
\text { routine } \\
\text { clinical care, } \\
\text { EAPs, com- } \\
\text { passionate } \\
\text { use programs, } \\
\text { and clinical } \\
\text { trials }\end{array}$ & & 1 & $255 / 1025$ & $\begin{array}{l}\text { Squamous } \\
+ \text { non- } \\
\text { squamous }\end{array}$ & Unselected & $\begin{array}{l}\text { Untreated } \\
\text { and } \\
\text { asymp- } \\
\text { tomatic } \\
\text { or } \\
\text { treated } \\
\text { and } \\
\text { stable } \\
\text { (stable or } \\
\text { decreas- } \\
\text { ing } \\
\text { symp- } \\
\text { toms } \\
\text { allowed) }\end{array}$ & $\begin{array}{l}\text { Anti-PD- } \\
1 \text { or } \\
\text { anti-PD- } \\
\text { L1 } \\
\text { monother- } \\
\text { apy }\end{array}$ & - & 15.8 & $\begin{array}{c}27.3 \\
\text { (PD-L1 } \\
\text { positive } \\
\text { patients } \\
(n=14): \\
35.7 \% ; \\
\text { PD-L1 } \\
\text { negative } \\
(n=9): \\
11.1 \%)\end{array}$ & - & $\begin{array}{l}20.6 \% \text { vs. } \\
22.7 \%\end{array}$ & & - & $\begin{array}{l}1.7 \\
(1.5-2.1) \\
\text { vs. 2.1 } \\
\text { (1.9-2.5) } \\
\text { (with } \\
\text { and } \\
\text { without } \\
\text { BM) }\end{array}$ & $\begin{array}{l}8.6 \\
(6.8- \\
12.0) \\
\text { vs. } \\
11.0 \\
(8.6- \\
13.8)\end{array}$ & $\begin{array}{c}\text { Multivariable analysis } \\
\text { showed that steroid use } \\
\text { (HR, 2.37) was associated } \\
\text { with poorer OS, whereas } \\
\text { stable BMs (HR, 0.62) } \\
\text { and higher ds-GPA } \\
\text { classification (HR, } \\
\text { 0.48-0.52) were } \\
\text { associated with } \\
\text { improved OS. }\end{array}$ \\
\hline $\begin{array}{c}\text { Crino, } \\
2017 \text { [19] }\end{array}$ & $\begin{array}{l}\text { Retrospective } \\
\text { (Italian EAP) }\end{array}$ & & $\geq 2$ & $409 / 1588$ & $\begin{array}{c}\text { Non- } \\
\text { squamous }\end{array}$ & - & Asymptom & tic Nivo & - & 6.1 & - & - & - & & - & - & - & - \\
\hline $\begin{array}{l}\text { Molinier, } \\
2017 \text { [20] }\end{array}$ & $\begin{array}{l}\text { Retrospective } \\
\text { (French EAP) }\end{array}$ & & $\geq 2$ & $130 / 600$ & $\begin{array}{l}\text { Squamous } \\
+ \text { non- } \\
\text { squamous }\end{array}$ & Unselected & NR & Nivo & & & $\begin{array}{c}12 \% \\
\text { partial } \\
\text { response }\end{array}$ & & & & & & 6.6 & $\begin{array}{c}7 \text { patients had all-grade } \\
\text { neurological symptoms, } \\
1(0.1 \%) \text { grade } 3 \text {, not } \\
\text { specified whether it was } \\
\text { BM patient or not. }\end{array}$ \\
\hline
\end{tabular}


Table 1. Cont.

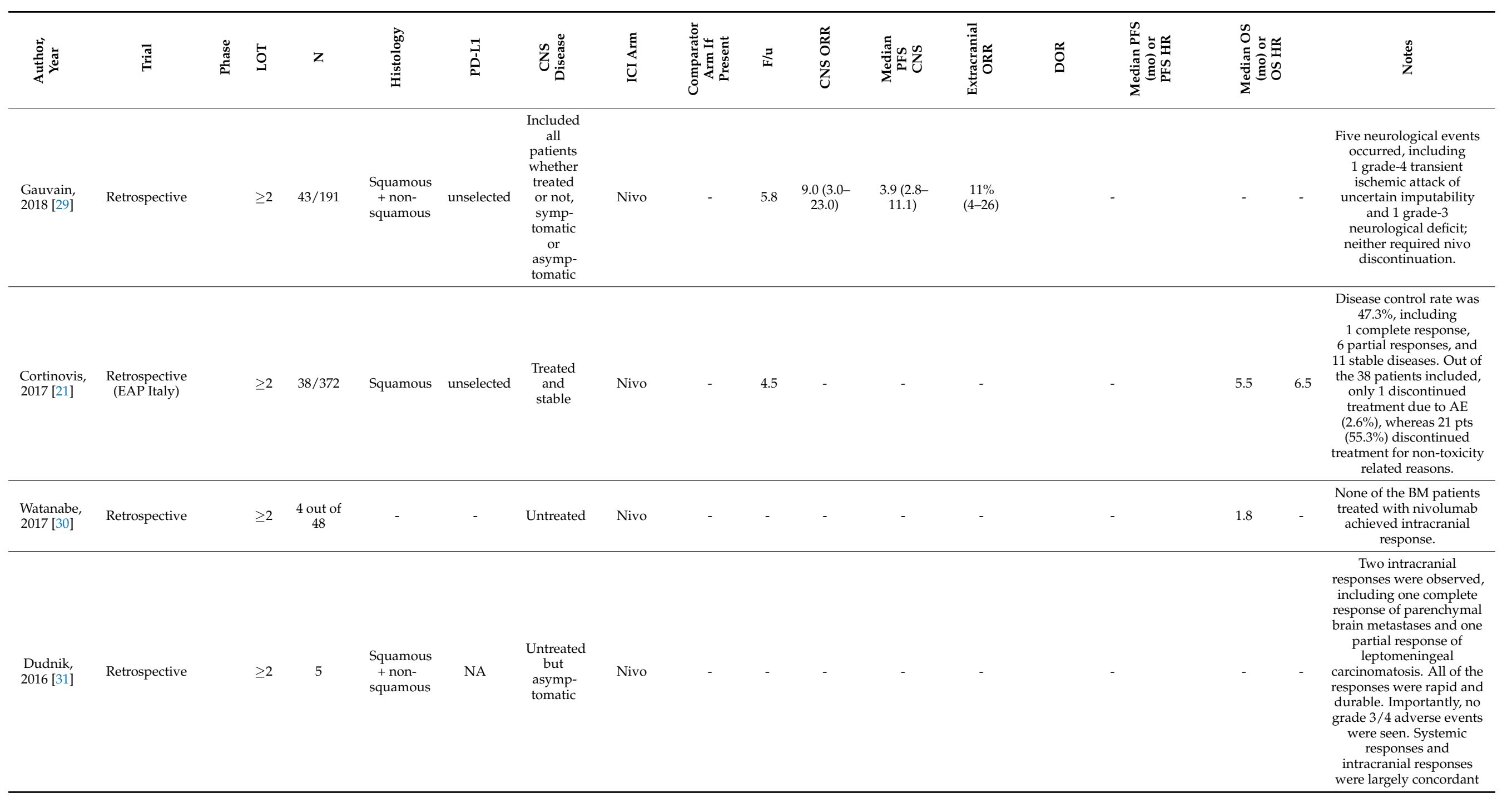


Table 1. Cont.

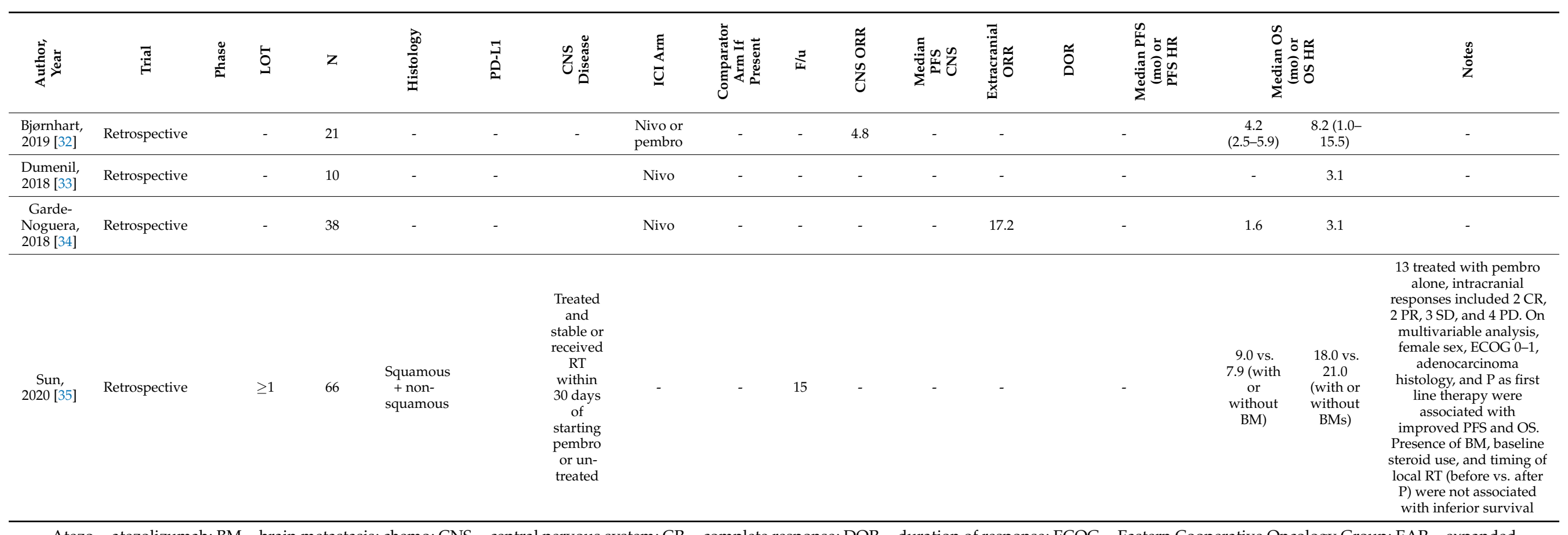

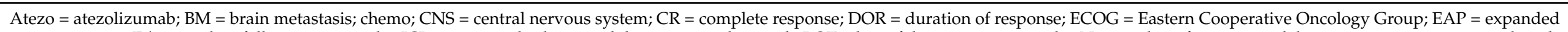

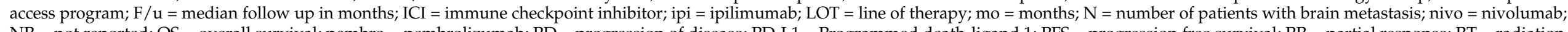

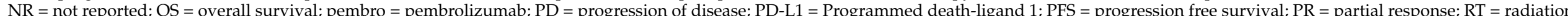
therapy; $\mathrm{SD}=$ stable disease. 
Table 2. Ongoing clinical trials with immune checkpoint inhibitors in patients with untreated brain metastases.

\begin{tabular}{|c|c|c|c|c|c|c|}
\hline $\begin{array}{l}\text { Clinicaltrials.Gov } \\
\text { Identifier }\end{array}$ & Phase & Disease & Major Inclusion Criteria & Steroids & Intervention & $\begin{array}{l}\text { Estimated } \\
\text { Enrollment }\end{array}$ \\
\hline NCT02681549 & II & $\begin{array}{l}\text { NSCLC and } \\
\text { melanoma }\end{array}$ & $\begin{array}{l}\text { At least one untreated BM } \\
5-20 \mathrm{~mm} \text {, asymptomatic, } \\
\text { and not requiring steroids, } \\
\text { PD-L1 positive } \\
\text { Untreated asymptomatic }\end{array}$ & Steroids not permitted & $\begin{array}{l}\text { Pembrolizumab } \\
\text { plus bevacizumab }\end{array}$ & 53 \\
\hline NCT02886585 & II & $\begin{array}{l}\text { NSCLC and } \\
\text { melanoma }\end{array}$ & $\begin{array}{c}\text { BM or progressive } \\
\text { asymptomatic BM } \\
\text { measuring } \geq 10 \mathrm{~mm} \text { or } \\
\text { cytology positive neoplastic } \\
\text { meningitis }\end{array}$ & $\begin{array}{l}\text { Stable dose of } \\
\text { dexamethasone } 2 \mathrm{mg} / \text { day } \\
\text { or less for } 7 \text { days prior to } \\
\text { initiation of treatment }\end{array}$ & Pembrolizumab & 102 \\
\hline NCT03526900 & II & NSCLC & $\begin{array}{c}\text { Untreated BM, } \\
\text { asymptomatic, and } \leq 4 \mathrm{mg} \\
\text { dexamethasone/day }\end{array}$ & $\begin{array}{c}\text { Up to } \leq 4 \mathrm{mg} \\
\text { dexamethasone/day } \\
\text { allowed as long as patients } \\
\text { are asymptomatic or } \\
\text { minimally symptomatic }\end{array}$ & $\begin{array}{l}\text { Atezolizumab } \\
\text { plus carboplatin } \\
\text { plus pemetrexed, } \\
\text { followed by } \\
\text { maintenance } \\
\text { atezolizumab } \\
\text { plus pemetrexed }\end{array}$ & 40 \\
\hline
\end{tabular}

$\mathrm{BM}=$ brain metastasis; NSCLC $=$ non-small cell lung cancer; PD-L1 = programmed death-ligand 1.

\subsection{Pretreated $B M s$}

\subsubsection{ICI Monotherapy}

Several post hoc analyses of ICIs in NSCLC patients with pretreated, asymptomatic, and stable BMs have been reported in recent years [18,24,25]. In a pooled analysis of NSCLC patients with BMs enrolled in three trials with nivolumab (CheckMate 063, 017, and 057), 46 patients who received nivolumab as second-line treatment displayed acceptable safety and promising efficacy when compared to docetaxel [24]. Similarly, in another pooled analysis of pembrolizumab monotherapy trials (KEYNOTE-001, 010, 024 and 042), pembrolizumab showed improved survival with pembrolizumab compared with chemotherapy, irrespective of BM at baseline [22].

\subsubsection{ICIs Combined with Chemotherapy}

The combination of ICIs with chemotherapy represents another recent advance in the treatment of advanced NSCLC patients, with multiple front-line trials showing the combination to be superior to chemotherapy alone [44]. A pooled analysis of pembrolizumab plus chemotherapy trials (KEYNOTE-021, 189, and 407) has shown the combination to improve survival irrespective of the presence or absence of BM at baseline (Table 3) [23].

\subsubsection{Dual ICI Therapy}

Borghaei et al. recently presented a post hoc analysis of the BM-positive cohort from the Checkmate 227 trial that randomized advanced NSCLC patients into first-line ipilimumab plus nivolumab versus chemotherapy [27]. The data suggested similar efficacy and safety of dual-ICI therapy for NSCLC patients irrespective of the presence or absence of BMs at baseline [27] (Table 3). 
Table 3. Summary of clinical studies with immune checkpoint inhibitor combinations in patients with brain metastases.

\begin{tabular}{|c|c|c|c|c|c|c|c|c|c|c|c|c|c|c|c|}
\hline $\begin{array}{l}\text { Author, } \\
\text { Year }\end{array}$ & Trial & Phase & LOT & $\mathrm{N}$ & Histology & PD-L1 & $\begin{array}{c}\text { CNS } \\
\text { Disease }\end{array}$ & ICI Arm & $\begin{array}{c}\text { Comparator } \\
\text { Arm, If } \\
\text { Present }\end{array}$ & $\mathbf{F} / \mathbf{u}$ & $\begin{array}{c}\text { Extracranial } \\
\text { ORR, \% }\end{array}$ & DOR, mo & $\begin{array}{c}\text { Median } \\
\text { PFS (mo) } \\
\text { or HR for } \\
\text { PFS }\end{array}$ & $\begin{array}{l}\text { Median } \\
\text { OS (mo) or } \\
\text { HR for OS }\end{array}$ & Notes \\
\hline \multicolumn{16}{|c|}{ Chemoimmunotherapy } \\
\hline $\begin{array}{c}\text { Afzal, } 2018 \\
\text { [45] }\end{array}$ & Retrospective & & $\geq 1$ & $18 / 54$ & $\begin{array}{c}\text { Non- } \\
\text { squamous }\end{array}$ & Unselected & $\begin{array}{c}\text { Treated } \\
\text { and stable }\end{array}$ & $\begin{array}{c}\text { Pembro + } \\
\text { chemo }\end{array}$ & & 30 & 80 & & 6.5 & 13.7 & - \\
\hline \multicolumn{16}{|c|}{ Dual ICI } \\
\hline $\begin{array}{l}\text { Borghaei, } \\
2020 \text { [27] }\end{array}$ & $\begin{array}{c}\text { Checkmate } \\
227\end{array}$ & III & 1 & $135 / 1739$ & $\begin{array}{l}\text { Squamous } \\
+ \text { non- } \\
\text { squamous }\end{array}$ & Unselected & $\begin{array}{c}\text { Treated } \\
\text { and stable }\end{array}$ & Ipi + nivo & Chemo & $\begin{array}{c}29.3 \\
\text { (minimum } \\
\text { follow-up) }\end{array}$ & $\begin{array}{c}33 \text { vs. } 26 \\
\text { [vs. } 33 \text { vs. } \\
28]\end{array}$ & $\begin{array}{c}24.9 \\
(11.3-\mathrm{NR}) \\
\text { vs. } 8.4 \\
(4.2-13.9) \\
\text { [vs. } 19.6 \\
(15.5-28.6) \\
\text { vs. } 5.8 \\
(4.8-6.9)]\end{array}$ & $\begin{array}{c}5.4 \text { vs. } 5.8 ; \\
0.79 \\
(0.52-1.19) \\
4.9 \text { [vs. } 5.4 ; \\
0.81 \\
(0.70-0.93)]\end{array}$ & $\begin{array}{c}18.8 \text { vs. } \\
13.7 ; 0.57 \\
(0.38-0.85) \\
\text { [vs. } 17.1 \text { vs. } \\
13.9 ; 0.76 \\
(0.66-0.88)]\end{array}$ & $\begin{array}{l}\text { Any-grade nervous } \\
\text { system adverse events } \\
\text { were reported in } 46 \% \text { of } \\
\text { pts with BM treated with } \\
\text { ipi + nivo and } 42 \% \text { of } \\
\text { those treated with chemo, } \\
\text { most were grade } 1-2 .\end{array}$ \\
\hline
\end{tabular}

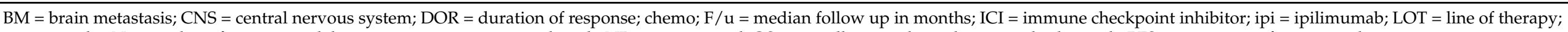
$\mathrm{mo}=$ months; $\mathrm{N}=$ number of patients with brain metastasis; nivo = nivolumab; $\mathrm{NR}=$ not reported; $\mathrm{OS}=$ overall survival; pembro = pembrolizumab; $\mathrm{PFS}=$ progression free survival. 


\section{Current Clinical Challenges}

Despite the favorable evidence suggesting that ICIs can provide intracranial responses in patients with untreated or treated BMs, several questions remain about the optimal use of ICIs in these patients, as discussed below.

\subsection{New Untreated (Systemic Therapy Naïve) BMs}

\subsubsection{Small Asymptomatic BMs}

Limited evidence, as discussed earlier, provides proof of principle that ICIs can induce objective intracranial responses in patients with BMs $[17,18]$. Preliminary data have shown durable responses that were concordant with extracranial response in most patients (almost $80 \%$ ) with NSCLC BMs, with intracranial ORRs approaching 30\% [18]. These data suggest that ICI might be an acceptable treatment option for select patients eligible for ICI with small (perhaps $<2 \mathrm{~cm}$ ), asymptomatic or minimally symptomatic, previously untreated brain metastasis. Patients treated with upfront ICI with deferred local therapy require careful clinical and imaging monitoring to detect CNS progression. For patients that are treated with upfront ICI and deferred local CNS therapy, short-interval imaging should be considered, which can be performed with contrast-enhanced magnetic resonance imaging (MRI) (or contrast-enhanced computed tomography if MRI is not possible) every 4-6 weeks in the beginning, followed by every 2 to 3 months.

\subsubsection{Large or Symptomatic BMs}

For patients with symptomatic BMs or multiple large BMs, rapid local control is crucial, as the progression of BMs can lead to rapid functional deterioration, impaired quality of life, or possibly death [46]. These patients often require a course of steroids to manage CNS symptoms in conjunction with upfront local CNS therapy in collaboration with a multidisciplinary team consisting of radiation oncologists and neurosurgeons [47]. Systemic treatment with ICI should be paused until steroids are tapered to a safe level given concerns of inferior efficacy of ICI with steroids [48]. Although there are no wellestablished data or thresholds for steroid use in this context, we suggest trying to taper dexamethasone to a dose of $2 \mathrm{mg}$ twice daily or less before initiation of ICIs.

\subsection{Treated BMs}

ICI therapies are acceptable treatment options for patients with treated NSCLC BMs given pooled data from numerous clinical trials of ICI monotherapy, ICI dual therapy, or ICI-chemotherapy showing similar survival outcomes in patients with or without baseline BMs [22-25,27].

\subsection{New BMs in Patients Receiving ICIs}

For patients who develop brain metastases as a site of progression during or after ICI, options for systemic therapy are limited, and control of CNS disease is often best achieved with either surgery and/or RT, with the choice and sequence of definitive CNS therapy depending on the number, size, and location of BMs, the extent of CNS symptoms, and overall performance status [47]. If BM represents the only site of disease progression, then surgical resection of an isolated metastasis with the continuation of ICI-based systemic therapy might be an option. However, most patients who develop progression of BMs on ICI will require local treatment along with a change in systemic therapy to subsequent line systemic therapy or clinical trials.

\section{Special Considerations in the Treatment of BM with ICIs}

\subsection{Timing of ICI with RT}

Despite concerns for increased risk of radiation necrosis, there is sparse data on the optimal timing and sequencing of RT and ICI in patients who require RT for symptomatic BMs [41]. Most retrospective studies have shown a manageable short-term safety profile 
for patients receiving intracranial RT concurrently for BMs while on ICI for extracranial disease [49].

\subsection{Risk of Radiation Necrosis with ICI and RT}

Radiation necrosis or treatment-induced brain tissue necrosis is a critical delayed complication of radiation therapy that usually develops 6 months to 2 years after radiation [50]. Radiation necrosis is thought to be more common with higher doses per fractionation and with concurrent chemotherapy or radiosensitizers, [51] and is thought to be more frequent with SRS, especially in the setting of concurrent administration of ICIs [52,53]. Radiation necrosis is difficult to distinguish from tumor recurrence radiographically and often requires biopsy or serial imaging, as radiation necrosis tends to regress spontaneously after an initial period of growth.

Development of radiation necrosis in patients receiving ICI can be challenging as these patients often require moderate to high doses of steroids that can potentially lower both intracranial and extracranial efficacy of ICIs [54]. In these scenarios, bevacizumab and surgery can be used selectively to control symptoms and facilitate steroid taper $[55,56]$.

\subsection{Leptomeningeal Disease}

Although ICI may be considered in this setting, data on ICI are extremely limited. For patients with increased intracranial pressure or hydrocephalus related to ICI, insertion of ventriculoperitoneal shunt should be considered to control intracranial pressure and allow time for ICI response. As in the case with BMs, in the absence of prospective data, it is difficult to draw any definitive conclusions regarding the optimal timing and sequencing of whole brain RT with ICIs.

\subsection{Pseudoprogression}

Pseudoprogression involves a transient enlargement of existing lesions or the appearance of new lesions mimicking tumor progression, which resolves on longitudinal imaging [57]. ICIs (particularly anti-CTLA-4 agents) have been known to result in pseudoprogression when used to treat BMs [58]. Imaging studies in patients with pseudoprogression often show an increased contrast enhancement and vasogenic edema (which can be small and asymptomatic), which usually occur within the first 3 months. These changes usually stabilize or subside on further follow-up without additional therapies. For minimally symptomatic lesions, close follow-up with serial imaging can avoid unnecessary tumor-directed therapies. Sometimes, a biopsy is needed to distinguish treatment-related changes from progressive tumors and to guide further therapy [58].

\subsection{CNS Toxicities with ICI Therapy for BMs}

Evaluating the actual clinical impact of neurologic adverse events in BM patients treated with ICIs is difficult given issues with assessing the adverse events as being tumor-associated inflammatory response, paraneoplastic, or truly autoimmune events, and variable reporting of neurotoxicity across trials [59]. The majority of data for ICI-related neurotoxicity in BM patients come from trials conducted in melanoma patients. CNS autoimmune toxicities due to ICIs are rare but can include myasthenia gravis, encephalitis, aseptic meningitis, and rarely, multiple sclerosis. Available studies on the use of ICIs in NSCLC BMs so far have reported a very low incidence of autoimmune CNS toxicities in these patients [59].

\subsection{Future Risk of New CNS BM Development}

In the OAK trial of subsequent line atezolizumab versus docetaxel, the risk of identifying new symptomatic brain lesions (patients were not required to undergo regularly scheduled follow-up scans and were instead symptom-driven) in patients with a history of asymptomatic, treated BM appeared to be lower than with docetaxel. In patients without $\mathrm{BM}$ at baseline, larger sample size and a longer follow-up period are needed to generate 
enough data to draw any meaningful conclusion regarding the future risk of BMs in patients treated with atezolizumab [26]. Similar results were seen in the pooled analysis of five studies (PCD4989g, BIRCH, FIR, POPLAR, and OAK) that evaluated subsequent-line atezolizumab versus docetaxel, with a lower risk of developing a new CNS lesion with atezolizumab (median time to develop a new CNS lesion, not reached versus 9.5 months; HR $0.42,95 \%$ CI, 0.15-1.18) [25].

Post hoc analysis of data from the Impower 150 trial showed that the combination of atezolizumab plus bevacizumab plus carboplatin plus paclitaxel $(\mathrm{ABCP})$ might delay the time to new BM development compared with atezolizumab plus carboplatin plus paclitaxel (ACP) [60]. Authors reported that with a minimum follow-up of 32.4 months (with the development of $\mathrm{BM}$ in 100 patients), $\mathrm{ABCP}$ regimen was associated with a lower rate of new $\mathrm{BM}$ development $(7.0 \%)$ compared with $\mathrm{ACP}(11.9 \%)$ and $\mathrm{BCB}(6.0 \%)$ regimens. Median time to develop new BMs was not reached in any arms; however, a trend toward delayed time to new $\mathrm{BM}$ development was seen in the $\mathrm{ABCP}$ arm versus the $\mathrm{BCP}$ arm (HR $0.68 ; 95 \%$ CI, 0.39-1.19). The rates of grade 3-4 treatment-related adverse events were similar between the patients with and without $\mathrm{BMs}$ but were slightly higher in the $\mathrm{ABCP}$ arm than the ACP and BCP arms [60].

\section{Conclusions and Future Directions}

Although only a few prospective ICI trials have included NSCLC patients with untreated BMs, preliminary results show encouraging intracranial activity of ICIs that are comparable to extracranial responses. Pooled analyses of the trials indicate that patients with BMs achieve similar OS compared to those without BMs. However, because only a highly select group of patients with previously treated or asymptomatic BMs have been treated in clinical trials so far, the broader applicability of these results to NSCLC patients is limited. Even though the PD-L1 tumor proportion score has been used as a predictive biomarker in the treatment of advanced NSCLC, it is unclear whether PD-L1 expression in extracranial lesions can be used to select BM patients for ICIs as some studies have suggested a low level of concordance in PD-L1 expression between primary and metastatic sites [61]. As it can be challenging to obtain tissues from the BMs to carry out PD-L1 testing, further studies are needed to clarify whether PD-L1 expression in BMs is needed for the intracranial benefit with ICIs. Some of the other areas that need to be explored include the risks of vasogenic edema and pseudoprogression with ICIs and the timing/sequencing of RT and ICIs. Finally, refinement in the intracranial disease response criteria and definitions of measurable disease are needed to standardize clinical trial conduct in patients with BMs.

NSCLC patients, including those with BMs, are living longer with the introduction of ICIs. Early evidence suggests acceptable safety and promising efficacy of ICIs even in patients with untreated BMs. Additional clinical trials and translational studies are needed to expand and refine the role of ICI in NSCLC patients with BMs.

Author Contributions: Conceptualization, R.P. and R.S.; methodology, R.P. and A.A.; validation, R.P., A.A. and A.H.; formal analysis, R.P., A.A., and A.H.; data curation, R.P. and A.A.; writing-original draft preparation, R.P., A.A. and A.H.; writing—review and editing, R.P., A.A., A.H., E.M. and R.S. All authors have read and agreed to the published version of the manuscript.

Funding: This research received no external funding.

Institutional Review Board Statement: Ethical review and approval were waived as this was a review article.

Informed Consent Statement: Patient consent was waived as this was a review article.

Data Availability Statement: No primary data reported.

Conflicts of Interest: A.A. reports speaker bureau fees from Astra Zeneca and Takeda Pharmaceuticals. E.M. reports speaker bureau fees from Astra Zeneca and Merck, and advisory board fees from Merck and Genentech. R.S. reports speaker bureau participation with AstraZeneca and Merck and 
is an advisory board member for Janssen and Novartis. The remaining authors declare no conflict of interest.

\section{References}

1. Cagney, D.N.; Martin, A.M.; Catalano, P.J.; Redig, A.J.; Lin, N.U.; Lee, E.Q.; Wen, P.Y.; Dunn, I.F.; Bi, W.L.; Weiss, S.E.; et al. Incidence and Prognosis of Patients with Brain Metastases at Diagnosis of Systemic Malignancy: A Population-Based Study. Neuro-Oncology 2017, 19, 1511-1521. [CrossRef] [PubMed]

2. Shin, D.-Y.; Na, I.I.; Kim, C.H.; Park, S.; Baek, H.; Yang, S.H. EGFR Mutation and Brain Metastasis in Pulmonary Adenocarcinomas. J. Thorac. Oncol. Off. Publ. Int. Assoc. Study Lung Cancer 2014, 9, 195-199. [CrossRef]

3. Zhang, I.; Zaorsky, N.G.; Palmer, J.D.; Mehra, R.; Lu, B. Targeting Brain Metastases in ALK-Rearranged Non-Small-Cell Lung Cancer. Lancet Oncol. 2015, 16, e510-521. [CrossRef]

4. Peters, S.; Bexelius, C.; Munk, V.; Leighl, N. The Impact of Brain Metastasis on Quality of Life, Resource Utilization and Survival in Patients with Non-Small-Cell Lung Cancer. Cancer Treat. Rev. 2016, 45, 139-162. [CrossRef] [PubMed]

5. El Rassy, E.; Botticella, A.; Kattan, J.; Le Péchoux, C.; Besse, B.; Hendriks, L. Non-Small Cell Lung Cancer Brain Metastases and the Immune System: From Brain Metastases Development to Treatment. Cancer Treat. Rev. 2018, 68, 69-79. [CrossRef] [PubMed]

6. Parvez, K.; Parvez, A.; Zadeh, G. The Diagnosis and Treatment of Pseudoprogression, Radiation Necrosis and Brain Tumor Recurrence. Int. J. Mol. Sci. 2014, 15, 11832-11846. [CrossRef]

7. Kurman, J.S.; Murgu, S.D. Hyperprogressive Disease in Patients with Non-Small Cell Lung Cancer on Immunotherapy. J. Thorac. Dis. 2018, 10, 1124-1128. [CrossRef]

8. Quail, D.F.; Joyce, J.A. The Microenvironmental Landscape of Brain Tumors. Cancer Cell 2017, 31, 326-341. [CrossRef]

9. Berghoff, A.S.; Venur, V.A.; Preusser, M.; Ahluwalia, M.S. Immune Checkpoint Inhibitors in Brain Metastases: From Biology to Treatment. Am. Soc. Clin. Oncol. Educ. Book 2016, e116-e122. [CrossRef]

10. Fridman, W.H.; Pagès, F.; Sautès-Fridman, C.; Galon, J. The Immune Contexture in Human Tumours: Impact on Clinical Outcome. Nat. Rev. Cancer 2012, 12, 298-306. [CrossRef]

11. Berghoff, A.S.; Lassmann, H.; Preusser, M.; Höftberger, R. Characterization of the Inflammatory Response to Solid Cancer Metastases in the Human Brain. Clin. Exp. Metastasis 2013, 30, 69-81. [CrossRef] [PubMed]

12. Berghoff, A.S.; Inan, C.; Ricken, G.; Widhalm, G.; Dieckmann, K.; Birner, P.; Oberndorfer, F.; Dome, B.; Bartsch, R.; Zielinski, C.; et al. 1324P - Tumor-Infiltrating Lymphocytes (Tils) and Pd-L1 Expression in Non- Small Cell Lung Cancer Brain Metastases (Bm) and Matched Primary Tumors (Pt). Ann. Oncol. 2014, 25, iv465. [CrossRef]

13. Berghoff, A.S.; Fuchs, E.; Ricken, G.; Mlecnik, B.; Bindea, G.; Spanberger, T.; Hackl, M.; Widhalm, G.; Dieckmann, K.; Prayer, D.; et al. Density of Tumor-Infiltrating Lymphocytes Correlates with Extent of Brain Edema and Overall Survival Time in Patients with Brain Metastases. Oncoimmunology 2016, 5, e1057388. [CrossRef]

14. Portnow, J.; Wang, D.; Blanchard, M.S.; Tran, V.; Alizadeh, D.; Starr, R.; Dodia, R.; Chiu, V.; Brito, A.; Kilpatrick, J.; et al. Systemic Anti-PD-1 Immunotherapy Results in PD-1 Blockade on T Cells in the Cerebrospinal Fluid. JAMA Oncol. 2020, 6, $1947-1951$. [CrossRef]

15. Louveau, A.; Smirnov, I.; Keyes, T.J.; Eccles, J.D.; Rouhani, S.J.; Peske, J.D.; Derecki, N.C.; Castle, D.; Mandell, J.W.; Kevin, S.L.; et al. Structural and Functional Features of Central Nervous System Lymphatics. Nature 2015, 523, 337-341. [CrossRef]

16. Engelhardt, B.; Vajkoczy, P.; Weller, R.O. The Movers and Shapers in Immune Privilege of the CNS. Nat. Immunol. 2017, 18, 123-131. [CrossRef] [PubMed]

17. Hellmann, M.D.; Rizvi, N.A.; Goldman, J.W.; Gettinger, S.N.; Borghaei, H.; Brahmer, J.R.; Ready, N.E.; Gerber, D.E.; Chow, L.Q.; Juergens, R.A.; et al. Nivolumab plus Ipilimumab as First-Line Treatment for Advanced Non-Small-Cell Lung Cancer (CheckMate 012): Results of an Open-Label, Phase 1, Multicohort Study. Lancet Oncol. 2017, 18, 31-41. [CrossRef]

18. Goldberg, S.B.; Schalper, K.A.; Gettinger, S.N.; Mahajan, A.; Herbst, R.S.; Chiang, A.C.; Lilenbaum, R.; Wilson, F.H.; Omay, S.B.; Yu, J.B.; et al. Pembrolizumab for Management of Patients with NSCLC and Brain Metastases: Long-Term Results and Biomarker Analysis from a Non-Randomised, Open-Label, Phase 2 Trial. Lancet Oncol. 2020, 21, 655-663. [CrossRef]

19. Crinò, L.; Bronte, G.; Bidoli, P.; Cravero, P.; Minenza, E.; Cortesi, E.; Garassino, M.C.; Proto, C.; Cappuzzo, F.; Grossi, F.; et al. Nivolumab and Brain Metastases in Patients with Advanced Non-Squamous Non-Small Cell Lung Cancer. Lung Cancer 2019, 129, 35-40. [CrossRef]

20. Molinier, O.; Audigier-Valette, C.; Cadranel, J.; Monnet, I.; Hureaux, J.; Hilgers, W.; Fauchon, E.; Fabre, E.; Besse, B.; Brun, P.; et al. OA 17.05 IFCT-1502 CLINIVO: Real-Life Experience with Nivolumab in 600 Patients (Pts) with Advanced Non-Small Cell Lung Cancer (NSCLC). J. Thorac. Oncol. 2017, 12, S1793. [CrossRef]

21. Cortinovis, D.; Chiari, R.; Catino, A.; Grossi, F.; DE Marinis, F.; Sperandi, F.; Piantedosi, F.; Vitali, M.; Parra, H.J.S.; Migliorino, M.R.; et al. Italian Cohort of the Nivolumab EAP in Squamous NSCLC: Efficacy and Safety in Patients With CNS Metastases. Anticancer Res. 2019, 39, 4265-4271. [CrossRef] [PubMed]

22. Mansfield, A.S.; Herbst, R.S.; Castro, G.; Hui, R.; Peled, N.; Kim, D.-W.; Novello, S.; Satouchi, M.; Wu, Y.-L.; Garon, E.B.; et al. $1482 \mathrm{O}$ - Outcomes with Pembrolizumab (Pembro) Monotherapy in Patients (Pts) with PD-L1-Positive NSCLC with Brain Metastases: Pooled Analysis of KEYNOTE-001, -010, -024, and -042. Ann. Oncol. 2019, 30, v604-v606. [CrossRef] 
23. Powell, S.F.; Abreu, D.R.; Langer, C.J.; Tafreshi, A.; Paz-Ares, L.; Kopp, H.-G.; Rodríguez-Cid, J.; Kowalski, D.; Cheng, Y.; Kurata, T.; et al. 1483PD - Pembrolizumab (Pembro) plus Platinum-Based Chemotherapy (Chemo) in NSCLC with Brain Metastases: Pooled Analysis of KEYNOTE-021, 189, and 407. Ann. Oncol. 2019, 30, v606-v607. [CrossRef]

24. Goldman, J.W.; Crino, L.; Vokes, E.E.; Holgado, E.; Reckamp, K.; Pluzanski, A.; Spigel, D.; Kohlhaeufl, M.; Garassino, M.; Chow, L.Q.; et al. P2.36: Nivolumab (Nivo) in Patients (Pts) With Advanced (Adv) NSCLC and Central Nervous System (CNS) Metastases (Mets): Track: Immunotherapy. J. Thorac. Oncol. 2016, 11, S238-S239. [CrossRef]

25. Lukas, R.V.; Gandhi, M.; O’Hear, C.; Hu, S.; Lai, C.; Patel, J.D. $81 \mathrm{O}$ - Safety and Efficacy Analyses of Atezolizumab in Advanced Non-Small Cell Lung Cancer (NSCLC) Patients with or without Baseline Brain Metastases. Ann. Oncol. 2017, 28, ii28. [CrossRef]

26. Gadgeel, S.M.; Lukas, R.V.; Goldschmidt, J.; Conkling, P.; Park, K.; Cortinovis, D.; de Marinis, F.; Rittmeyer, A.; Patel, J.D.; von Pawel, J.; et al. Atezolizumab in Patients with Advanced Non-Small Cell Lung Cancer and History of Asymptomatic, Treated Brain Metastases: Exploratory Analyses of the Phase III OAK Study. Lung Cancer 2019, 128, 105-112. [CrossRef]

27. Borghaei, H.; Pluzanski, A.; Caro, R.B.; Provencio, M.; Burgers, S.; Carcereny, E.; Park, K.; Alexandru, A.; Lupinacci, L.; Sangha, R.; et al. Nivolumab (Nivo) + Ipilimumab (Ipi) as First-Line (1L) Treatment for Patients with Advanced Non-Small Cell Lung Cancer (NSCLC) with Brain Metastases: Results from the CheckMate 227. Presented at the AACR Virtual Annual Meeting II, Philadelphia, PA, USA, 22-24 June 2020.

28. Hendriks, L.E.L.; Henon, C.; Auclin, E.; Mezquita, L.; Ferrara, R.; Audigier-Valette, C.; Mazieres, J.; Lefebvre, C.; Rabeau, A.; Le Moulec, S.; et al. Outcome of Patients with Non-Small Cell Lung Cancer and Brain Metastases Treated with Checkpoint Inhibitors. J. Thorac. Oncol. Off. Publ. Int. Assoc. Study Lung Cancer 2019, 14, 1244-1254. [CrossRef]

29. Gauvain, C.; Vauléon, E.; Chouaid, C.; Le Rhun, E.; Jabot, L.; Scherpereel, A.; Vinas, F.; Cortot, A.B.; Monnet, I. Intracerebral Efficacy and Tolerance of Nivolumab in Non-Small-Cell Lung Cancer Patients with Brain Metastases. Lung Cancer Amst. Neth. 2018, 116, 62-66. [CrossRef]

30. Watanabe, H.; Kubo, T.; Ninomiya, T.; Ohashi, K.; Ichihara, E.; Sato, A.; Hotta, K.; Tabata, M.; Kiura, K. The Effect of Nivolumab Treatment for Central Nervous System Metastases in Non-Small Cell Lung Cancer. J. Clin. Oncol. 2017, 35, e20601. [CrossRef]

31. Dudnik, E.; Yust-Katz, S.; Nechushtan, H.; Goldstein, D.A.; Zer, A.; Flex, D.; Siegal, T.; Peled, N. Intracranial Response to Nivolumab in NSCLC Patients with Untreated or Progressing CNS Metastases. Lung Cancer 2016, 98, 114-117. [CrossRef]

32. Bjørnhart, B.; Hansen, K.H.; Jørgensen, T.L.; Herrstedt, J.; Schytte, T. Efficacy and Safety of Immune Checkpoint Inhibitors in a Danish Real Life Non-Small Cell Lung Cancer Population: A Retrospective Cohort Study. Acta Oncol. $2019,58,953-961$. [CrossRef] [PubMed]

33. Dumenil, C.; Massiani, M.-A.; Dumoulin, J.; Giraud, V.; Labrune, S.; Chinet, T.; Leprieur, E.G. Clinical Factors Associated with Early Progression and Grade 3-4 Toxicity in Patients with Advanced Non-Small-Cell Lung Cancers Treated with Nivolumab. PLOS ONE 2018, 13, e0195945. [CrossRef] [PubMed]

34. Garde-Noguera, J.; Martin-Martorell, P.; De Julián, M.; Perez-Altozano, J.; Salvador-Coloma, C.; García-Sanchez, J.; Insa-Molla, A.; Martín, M.; Mielgo-Rubio, X.; Marin-Liebana, S.; et al. Predictive and Prognostic Clinical and Pathological Factors of Nivolumab Efficacy in Non-Small-Cell Lung Cancer Patients. Clin. Transl. Oncol. 2018, 20, 1072-1079. [CrossRef] [PubMed]

35. Sun, L.; Davis, C.; Marmarelis, M.E.; Jeffries, S.; Sulyok, L.F.; Hwang, W.-T.; Singh, A.P.; Berman, A.T.; Feigenberg, S.J.; Levin, W.C.; et al. Outcomes in Patients with Metastatic Non-Small Cell Lung Cancer (MNSCLC) with Brain Metastases Treated with Pembrolizumab-Based Therapy. J. Clin. Oncol. 2020, 38, 9599. [CrossRef]

36. Lin, N.U.; Lee, E.Q.; Aoyama, H.; Barani, I.J.; Barboriak, D.P.; Baumert, B.G.; Bendszus, M.; Brown, P.D.; Camidge, D.R.; Chang, S.M.; et al. Response Assessment Criteria for Brain Metastases: Proposal from the RANO Group. Lancet Oncol. 2015, 16, e270-e278. [CrossRef]

37. Twyman-Saint Victor, C.; Rech, A.J.; Maity, A.; Rengan, R.; Pauken, K.E.; Stelekati, E.; Benci, J.L.; Xu, B.; Dada, H.; Odorizzi, P.M.; et al. Radiation and Dual Checkpoint Blockade Activate Non-Redundant Immune Mechanisms in Cancer. Nature 2015, 520, 373-377. [CrossRef]

38. Ngwa, W.; Irabor, O.C.; Schoenfeld, J.D.; Hesser, J.; Demaria, S.; Formenti, S.C. Using Immunotherapy to Boost the Abscopal Effect. Nat. Rev. Cancer 2018, 18, 313-322. [CrossRef]

39. Demaria, S.; Golden, E.B.; Formenti, S.C. Role of Local Radiation Therapy in Cancer Immunotherapy. JAMA Oncol. 2015, 1, 1325-1332. [CrossRef]

40. Dovedi, S.J.; Adlard, A.L.; Lipowska-Bhalla, G.; McKenna, C.; Jones, S.; Cheadle, E.J.; Stratford, I.J.; Poon, E.; Morrow, M.; Stewart, R.; et al. Acquired Resistance to Fractionated Radiotherapy Can Be Overcome by Concurrent PD-L1 Blockade. Cancer Res. 2014, 74, 5458-5468. [CrossRef]

41. Petrelli, F.; De Stefani, A.; Trevisan, F.; Parati, C.; Inno, A.; Merelli, B.; Ghidini, M.; Bruschieri, L.; Vitali, E.; Cabiddu, M.; et al. Combination of Radiotherapy and Immunotherapy for Brain Metastases: A Systematic Review and Meta-Analysis. Crit. Rev. Oncol. Hematol. 2019, 144, 102830. [CrossRef]

42. Lehrer, E.J.; Peterson, J.; Brown, P.D.; Sheehan, J.P.; Quiñones-Hinojosa, A.; Zaorsky, N.G.; Trifiletti, D.M. Treatment of Brain Metastases with Stereotactic Radiosurgery and Immune Checkpoint Inhibitors: An International Meta-Analysis of Individual Patient Data. Radiother. Oncol. J. Eur. Soc. Ther. Radiol. Oncol. 2019, 130, 104-112. [CrossRef]

43. Ahmed, K.A.; Kim, S.; Arrington, J.; Naghavi, A.O.; Dilling, T.J.; Creelan, B.C.; Antonia, S.J.; Caudell, J.J.; Harrison, L.B.; Sahebjam, S.; et al. Outcomes Targeting the PD-1/PD-L1 Axis in Conjunction with Stereotactic Radiation for Patients with Non-Small Cell Lung Cancer Brain Metastases. J. Neurooncol. 2017, 133, 331-338. [CrossRef] 
44. Goldberg, S.B.; Herbst, R.S. Should Chemotherapy plus Immune Checkpoint Inhibition Be the Standard Front-Line Therapy for Patients with Metastatic Non-Small Cell Lung Cancer? Cancer 2018, 124, 4592-4596. [CrossRef]

45. Afzal, M.Z.; Dragnev, K.; Shirai, K. A Tertiary Care Cancer Center Experience with Carboplatin and Pemetrexed in Combination with Pembrolizumab in Comparison with Carboplatin and Pemetrexed Alone in Non-Squamous Non-Small Cell Lung Cancer. J. Thorac. Dis. 2018, 10. [CrossRef]

46. Verhaak, E.; Gehring, K.; Hanssens, P.E.J.; Aaronson, N.K.; Sitskoorn, M.M. Health-Related Quality of Life in Adult Patients with Brain Metastases after Stereotactic Radiosurgery: A Systematic, Narrative Review. Support. Care Cancer 2020, 28, $473-484$. [CrossRef] [PubMed]

47. Moravan, M.J.; Fecci, P.E.; Anders, C.K.; Clarke, J.M.; Salama, A.K.S.; Adamson, J.D.; Floyd, S.R.; Torok, J.A.; Salama, J.K.; Sampson, J.H.; et al. Current Multidisciplinary Management of Brain Metastases. Cancer 2020, 126, 1390-1406. [CrossRef] [PubMed]

48. Arbour, K.C.; Mezquita, L.; Long, N.; Rizvi, H.; Auclin, E.; Ni, A.; Martínez-Bernal, G.; Ferrara, R.; Lai, W.V.; Hendriks, L.E.L.; et al. Impact of Baseline Steroids on Efficacy of Programmed Cell Death-1 and Programmed Death-Ligand 1 Blockade in Patients With Non-Small-Cell Lung Cancer. J. Clin. Oncol. Off. J. Am. Soc. Clin. Oncol. 2018, 36, 2872-2878. [CrossRef] [PubMed]

49. Hubbeling, H.G.; Schapira, E.F.; Horick, N.K.; Goodwin, K.E.H.; Lin, J.J.; Oh, K.S.; Shaw, A.T.; Mehan, W.A.; Shih, H.A.; Gainor, J.F. Safety of Combined PD-1 Pathway Inhibition and Intracranial Radiation Therapy in Non-Small Cell Lung Cancer. J. Thorac. Oncol. Off. Publ. Int. Assoc. Study Lung Cancer 2018, 13, 550-558. [CrossRef] [PubMed]

50. Le Rhun, E.; Dhermain, F.; Vogin, G.; Reyns, N.; Metellus, P. Radionecrosis after Stereotactic Radiotherapy for Brain Metastases. Expert Rev. Neurother. 2016, 16, 903-914. [CrossRef]

51. Ruben, J.D.; Dally, M.; Bailey, M.; Smith, R.; McLean, C.A.; Fedele, P. Cerebral Radiation Necrosis: Incidence, Outcomes, and Risk Factors with Emphasis on Radiation Parameters and Chemotherapy. Int. J. Radiat. Oncol. Biol. Phys. 2006, 65, 499-508. [CrossRef]

52. Chao, S.T.; Ahluwalia, M.S.; Barnett, G.H.; Stevens, G.H.J.; Murphy, E.S.; Stockham, A.L.; Shiue, K.; Suh, J.H. Challenges with the Diagnosis and Treatment of Cerebral Radiation Necrosis. Int. J. Radiat. Oncol. Biol. Phys. 2013, 87, 449-457. [CrossRef]

53. Colaco, R.J.; Martin, P.; Kluger, H.M.; Yu, J.B.; Chiang, V.L. Does Immunotherapy Increase the Rate of Radiation Necrosis after Radiosurgical Treatment of Brain Metastases? J. Neurosurg. 2016, 125, 17-23. [CrossRef]

54. Petrelli, F.; Signorelli, D.; Ghidini, M.; Ghidini, A.; Pizzutilo, E.G.; Ruggieri, L.; Cabiddu, M.; Borgonovo, K.; Dognini, G.; Brighenti, M.; et al. Association of Steroids Use with Survival in Patients Treated with Immune Checkpoint Inhibitors: A Systematic Review and Meta-Analysis. Cancers 2020, 12, 546. [CrossRef]

55. Glitza, I.C.; Guha-Thakurta, N.; D'Souza, N.M.; Amaria, R.N.; McGovern, S.L.; Rao, G.; Li, J. Bevacizumab as an Effective Treatment for Radiation Necrosis after Radiotherapy for Melanoma Brain Metastases. Melanoma Res. 2017, 27, 580-584. [CrossRef]

56. McPherson, C.M.; Warnick, R.E. Results of Contemporary Surgical Management of Radiation Necrosis Using Frameless Stereotaxis and Intraoperative Magnetic Resonance Imaging. J. Neurooncol. 2004, 68, 41-47. [CrossRef] [PubMed]

57. Borcoman, E.; Nandikolla, A.; Long, G.; Goel, S.; Le Tourneau, C. Patterns of Response and Progression to Immunotherapy. Am. Soc. Clin. Oncol. Educ. Book 2018, 169-178. [CrossRef] [PubMed]

58. Melian, M.; Lorente, D.; Aparici, F.; Juan, O. Lung Brain Metastasis Pseudoprogression after Nivolumab and Ipilimumab Combination Treatment. Thorac. Cancer 2018, 9, 1770-1773. [CrossRef] [PubMed]

59. Tran, T.T.; Jilaveanu, L.B.; Omuro, A.; Chiang, V.L.; Huttner, A.; Kluger, H.M. Complications Associated with Immunotherapy for Brain Metastases. Curr. Opin. Neurol. 2019, 32, 907-916. [CrossRef] [PubMed]

60. Cappuzzo, F.; Reck, M.; Socinski, M.A.; Mok, T.S.K.; Jotte, R.M.; Finley, G.G.; Rodriguez-Abreu, D.; Aerts, J.; West, H.; Nishio, M.; et al. IMpower150: Exploratory Analysis of Brain Metastases Development. J. Clin. Oncol. 2020, 38, 9587. [CrossRef]

61. Kim, S.; Koh, J.; Kwon, D.; Keam, B.; Go, H.; Kim, Y.A.; Jeon, Y.K.; Chung, D.H. Comparative Analysis of PD-L1 Expression between Primary and Metastatic Pulmonary Adenocarcinomas. Eur. J. Cancer 2017, 75, 141-149. [CrossRef] 